\title{
Choleris Students' Critical Thinking Process in Mathematics Problem Solving
}

\author{
Moh. Syukron Maftuh ${ }^{1 *}$, Nur Fathonah ${ }^{2}$, Ina Nur Roihah ${ }^{3}$ \\ 1,2,3 Universitas PGRI Adi Buana Surabaya \\ *syukron@unipasby.ac.id
}

Received: May 2021. Accepted: June 2021. Published: July 2021.

\begin{abstract}
The purpose of this study was to describe the critical thinking process of junior high school students with choleric personalities in solving mathematical problems. This research is a descriptive study with a qualitative approach. The subjects in this study were two students of MTs Hasanuddin Sidoarjo class VIII who had choleric personalities obtained from the results of personality tests. The research stages used by the researchers consisted of three stages, namely the preparation stage, the implementation stage, and the analysis stage. The data collection technique in this research is the technique of giving the Mathematical Problem Solving Test (TPMM) and interviews later to obtain valid and credible data, researchers use source triangulation. Based on the results of data analysis, it can be concluded that the choleric subject in solving mathematical problems shows the criteria for critical thinking: focus, reason, inference, situation, clarity, overview at the stage of understanding the problem. At the stage of making a plan for the completion of the choleric subject, it fulfills the criteria for critical thinking, focus, reason, inference, situation, clarity, overview. Likewise, at the stage of implementing the completion plan, the choleric subject meets the criteria for critical thinking, focus, reason, inference, situation, clarity, overview. Meanwhile, at the stage of re-examining the completion plan, the choleric subject only met the criteria for critical thinking, focus, reason, inference, situation, clarity, did not meet the criteria for critical thinking overview.

Keywords: critical thinking, mathematical problem solving, choleric personality
\end{abstract}

How to Cite: Maftuh, M. S., Fathonah, \& Roihah, I. N. (2021). Choleris Students' Critical Thinking Process in Mathematics Problem Solving. Journal of Medives: Journal of Mathematics Education IKIP Veteran Semarang, 5(2), 329-338. 


\section{PENDAHULUAN}

Matematika merupakan ilmu yang memiliki peranan penting dalam membentuk pola pikir manusia. Seiring dengan berkembangnya zaman kebutuhan akan pelajaran matematika semakin meningkat. Menurut Depdiknas (2006) mata pelajaran matematika diberikan untuk siswa mulai dari jenjang sekolah dasar sampai menengah atas untuk memberikan bekal berupa kemampuan berpikir logis, kritis, sistematis, kreatif, dan analisis. Setiap manusia diciptakan disertai dengan akal pikiran yang digunakan untuk berpikir. Menurut Krulik dan Rudnick (dalam Arini wahyu et al. 2018) kebanyakan keterampilan berpikir terbentuk dari empat tingkatan yaitu: menghafal (recall thinking), dasar (basic thinking), kritis (critical thinking), dan kreatif (creative thinking). Menurut Ennis (dalam Siswono, 2018) mengatakan bahwa berpikir kritis adalah suatu usaha yang bertujuan untuk membuat keputusan yang masuk akal mengenai sesuatu yang dipercayai dan dilakukan. Adapun enam tahapan berpikir kritis menurut Ennis (dalam Saudi et al., 2018) yaitu: focus, reason, inference, situation, clarity, dan overview.

Ciri siswa yang berpikir kritis di antaranya adalah selalu mencari solusi dari permasalahan yang dihadapi, sering bertanya dan mempunyai keterampilan menalar dalam memecahkan suatu masalah. Seseorang dikatakan berpikir kritis bisa dilihat saat orang tersebut bertingkah laku sesuai dengan indikator yang dikemukakan oleh para ahli. Ennis mencetuskan indikator yang bisa menunjukkan kemampuan berpikir kritis seseorang (Hidayanti et al., 2020). Indikator berpikir kritis menurut Ennis disajikan pada Tabel 1.

Siswa yang kritis akan selalu mencari solusi dari permasalahan yang dihadapi, sering bertanya dan mempunyai keterampilan menalar dalam memecahkan suatu masalah (Yustitia \& Siswono, 2021). Dengan demikian dapat diambil kesimpulan bahwa berpikir kritis sangat diperlukan dalam pembelajaran matematika untuk dikembangkan dan dilatih sejak dini, salah satunya dengan melatih berpikir kritis siswa dalam pemecahan masalah matematika.

Tabel 1. Indikator Berpikir Kritis

\begin{tabular}{|c|c|c|}
\hline No. & Kriteria & Indikator \\
\hline 1 & $\mathrm{~F}($ Rocus $)$ & $\begin{array}{l}\text { Identifikasi fokus atau ketertarikan utama siswa mencerna masalaha pada } \\
\text { soal yang diberikan. }\end{array}$ \\
\hline 2 & $\mathrm{R}$ (Reason) & $\begin{array}{l}\text { Siswa memberikan keterangan berdasarkan fakta atau realitas yang releven } \\
\text { pada setiap langkah dalam membentuk keputusan maupun kesimpulan. }\end{array}$ \\
\hline 3 & I (Inference) & $\begin{array}{l}\text { Menilai kualitas simpulan, dengan spekulasi alasan untuk bisa diterima atau } \\
\text { siswa membuat simpulan dengan tepat dan siswa memilih alasan yang tepat } \\
\text { untuk mendukung simpulan yang dibuat. }\end{array}$ \\
\hline 4 & $\mathrm{~S}$ (Situation) & Siswa menggunakan semua keterangan yang sesuai dengan permasalahan. \\
\hline 5 & $\mathrm{C}($ Clarity $)$ & $\begin{array}{l}\text { Kejelasan, selidiki untuk memeriksa bahasanya jelas atau siswa memberikan } \\
\text { pengertian lebih lanjut tentang apa yang dimaksudkan dalam simpulan yang } \\
\text { dibuat. } \\
\text { Siswa dapat menerangkan istilah dalam soal jika ada siswa dapat } \\
\text { memberikan contoh permasalahan yang mirip dengan soal tersebut. }\end{array}$ \\
\hline 6 & $\mathrm{O}($ Overview $)$ & $\begin{array}{l}\text { Mengecek ulang secara keseluruhan atau siswa memeriksa kembali secara } \\
\text { menyeluruh mulai dari awal sampai akhir (yang dihasilkan pada FRISCO). }\end{array}$ \\
\hline
\end{tabular}


Tabel 2. Kriteria Berpikir Kritis pada Setiap Langkah Pemecahan Masalah

\begin{tabular}{|c|c|c|c|c|}
\hline Kriteria & Memahami Masalah & $\begin{array}{l}\text { Membuat } \\
\text { Rencana }\end{array}$ & $\begin{array}{c}\text { Melaksanakan } \\
\text { Rencana }\end{array}$ & $\begin{array}{c}\text { Memeriksa } \\
\text { Kembali }\end{array}$ \\
\hline Focus & $\begin{array}{l}\text { Membangun makna } \\
\text { tentang masalah apa } \\
\text { yang akan dipecahkan } \\
\text { dengan cara merumuskan } \\
\text { kembali masalah dengan } \\
\text { model matematika, } \\
\text { gambar, grafik, dll. }\end{array}$ & $\begin{array}{l}\text { Memutuskan stra- } \\
\text { tegi apa yang } \\
\text { akan dipakai un- } \\
\text { tuk memecahkan } \\
\text { masalah. }\end{array}$ & $\begin{array}{l}\text { Langkah-langkah } \\
\text { penerapan strategi } \\
\text { yang telah dipilih. }\end{array}$ & $\begin{array}{l}\text { Keputusan un- } \\
\text { tuk memeriksa } \\
\text { jawaban yang } \\
\text { diperoleh. }\end{array}$ \\
\hline Reason & $\begin{array}{l}\text { Memberikan alasan } \\
\text { terhadap hasil } \\
\text { rangkuman masalah yang } \\
\text { telah dibangun. }\end{array}$ & $\begin{array}{l}\text { Memberikan } \\
\text { alasan mengapa } \\
\text { menggunakan } \\
\text { rancangan } \\
\text { tersebut. }\end{array}$ & $\begin{array}{l}\text { Memberikan } \\
\text { alasan langkah } \\
\text { penerapannya. }\end{array}$ & $\begin{array}{l}\text { Memberikan } \\
\text { alasan mengapa } \\
\text { memeriksa } \\
\text { jawaban } \\
\text { tersebut. }\end{array}$ \\
\hline Inference & $\begin{array}{l}\text { Proses penarikan simpul- } \\
\text { an yang masuk akal } \\
\text { menurut penyelidikan } \\
\text { (tidak bertentangan } \\
\text { dengan informasi yang } \\
\text { ada) dari rangkaian } \\
\text { keterangn yang dikemu- } \\
\text { kakan sampai pada } \\
\text { penarikan kesimpulan. }\end{array}$ & $\begin{array}{l}\text { Proses penarikan } \\
\text { simpulan yang } \\
\text { masuk akal dari } \\
\text { rangkaian alasan } \\
\text { menggunakan } \\
\text { rancangan ter- } \\
\text { tentu sampai pada } \\
\text { keputusan untuk } \\
\text { menggunakan } \\
\text { rancangan } \\
\text { tersebut. }\end{array}$ & $\begin{array}{l}\text { Proses penarikan } \\
\text { simpulan yang } \\
\text { masuk akal } \\
\text { menurut uraian } \\
\text { dari rangkaian } \\
\text { alasan sampai } \\
\text { keputusan } \\
\text { langkah-langkah } \\
\text { penerapannya. }\end{array}$ & $\begin{array}{l}\text { Proses penarik- } \\
\text { an simpulan } \\
\text { yang masuk akal } \\
\text { dari urutan ala- } \\
\text { san sampai per- } \\
\text { nyataan untuk } \\
\text { meninjau kem- } \\
\text { bali jawaban. }\end{array}$ \\
\hline Situation & $\begin{array}{l}\text { Mengetahui apa yang } \\
\text { diketahui dan apa yang } \\
\text { ditanyakan dalam soal. }\end{array}$ & $\begin{array}{l}\text { Mengetahui hal- } \\
\text { hal penting yang } \\
\text { perlu diperhatikan } \\
\text { dalam membuat } \\
\text { rencana yaitu } \\
\text { mengetahui apa } \\
\text { yang harus dila- } \\
\text { kukan dalam } \\
\text { menerapkan } \\
\text { strategi. }\end{array}$ & $\begin{array}{l}\text { Mengetahui hal } \\
\text { hal penting yang } \\
\text { perlu diperhatikan } \\
\text { dalam langkah } \\
\text { langkah penerap- } \\
\text { an strategi. }\end{array}$ & $\begin{array}{l}\text { Mengetahui hal } \\
\text { hal penting yang } \\
\text { perlu diperhati- } \\
\text { kan dalam me- } \\
\text { meriksa jawaban } \\
\text { yang diperoleh. }\end{array}$ \\
\hline Clarity & $\begin{array}{l}\text { Menjelaskan istilah yang } \\
\text { digunakan (dikroscek } \\
\text { melalui wawancara). }\end{array}$ & $\begin{array}{l}\text { Menjelaskan } \\
\text { istilah yang } \\
\text { digunakan } \\
\text { (dikroscek } \\
\text { melalui } \\
\text { wawancara). }\end{array}$ & $\begin{array}{l}\text { Menjelaskan } \\
\text { istilah yang } \\
\text { digunakan } \\
\text { (dikroscek } \\
\text { melalui } \\
\text { wawancara). }\end{array}$ & $\begin{array}{l}\text { Menjelaskan } \\
\text { istilah yang } \\
\text { digunakan } \\
\text { (dikroscek } \\
\text { melalui } \\
\text { wawancara). }\end{array}$ \\
\hline Overview & $\begin{array}{l}\text { Mengecek semua bagian } \\
\text { yang telah dilakukan dari } \\
\text { alasan yang diberikan } \\
\text { sampai pada kesimpulan } \\
\text { apakah semuanya masuk } \\
\text { akal }\end{array}$ & $\begin{array}{l}\text { Mengecek semua } \\
\text { bagian yang telah } \\
\text { dilakukan dari } \\
\text { alasan yang di- } \\
\text { berikan sampai } \\
\text { pada keputusan } \\
\text { tentang strategi } \\
\text { yang akan } \\
\text { digunakan apakah } \\
\text { semuanya masuk } \\
\text { akal. }\end{array}$ & $\begin{array}{l}\text { Mengecek semua } \\
\text { bagian yang telah } \\
\text { dilakukan dari } \\
\text { alasan yang } \\
\text { diberikan sampai } \\
\text { pada langkah } \\
\text { langkah penerap- } \\
\text { an strategi apakah } \\
\text { semuanya masuk } \\
\text { akal. }\end{array}$ & $\begin{array}{l}\text { Mengecek se- } \\
\text { mua bagian } \\
\text { yang telah } \\
\text { dilakukan dan } \\
\text { alasan yang } \\
\text { diberikan sam- } \\
\text { pai pada kesim- } \\
\text { pulan untuk } \\
\text { memeriksa } \\
\text { jawaban apakah } \\
\text { semuanya } \\
\text { masuk akal. }\end{array}$ \\
\hline
\end{tabular}


Polya (1973) menyatakan bahwa pemecahan masalah adalah usaha untuk mencari solusi dari suatu permasalahan. Suatu soal matematika dikatakan sebagai pemecahan masalah apabila siswa secara tidak langsung dapat menemukan jawaban dari soal tersebut atau tidak dapat dijawab dengan prosedur rutin (Via, 2015). Oleh karena itu, siswa perlu diberikan latihan pemecahan masalah agar dapat mengambil keputusan dalam situasi yang berbeda. Adapun langkahlangkah pemecahan masalah berdasarkan teori Polya adalah: (1) memahami masalah, (2) membuat rencana penyelesaian, (3) melaksanakan rencana penyelesaian, dan (4) memeriksa kembali kebenaran solusi. Tujuan diajarkannya pemecahan masalah diantaranya adalah untuk mengembangkan keterampilan berpikir kritis siswa. Karena berpikir kritis berkaitan erat dengan pemecahan masalah. Dalam pemecahan masalah pasti setiap orang membutuhkan keterampilan berpikir kritis untuk dapat menemukan solusi dari pemecahan masalah, begitupun sebaliknya seorang siswa yang terbiasa memecahkan masalah matematika maka akan meningkatkan kemampuan berpikir kritisnya dalam pemecahan masalah. Tabel 2 menunjukkan kriteria berpikir kritis Frisco pada setiap langkah pemecahan masalah Polya (Peter, 2012; Chukwuyenum, 2013; Dewanti, 2018).

Selain pemecahan masalah sebagai tujuan umum dari pembelajaran matematika, karakteristik siswa juga memiliki kontribusi yang sangat penting dalam pemecahan masalah. Ini disebabkan oleh adanya perbedaan kepribadian dan perilaku siswa tersebut, sehingga tidak akan sama penyelesaian antara siswa yang satu dengan yang lain. Ada berbagai macam teori yang digunakan untuk memahami kepribadian siswa, di antaranya adalah teori kepribadian yang dikemukakan oleh Hippocrates-Galenus dalam bukunya Florence Littauer. Tipe kepribadian seseorang digolongkan menjadi empat yaitu: (1) choleris, (2) melancholis, (3) sanguinis, dan (4) phlegmatis. Siswa dengan kepribadian choleris mempunyai kemauan yang kuat dan tegas, optimis, suka bersaing, mandiri dan aktif dalam mengerjakan sesuatu, mencari solusi dari pemecahan masalah yang belum ditemukan jawabannya, mempunyai kemauan yang kuat untuk memperoleh hasil yang dicapai, dan selalu memperbaiki kesalahan. Dengan demikian, mengetahui kepribadian yang dimiliki oleh siswa diharapkan dapat membantu siswa untuk meningkatkan kemampuan berpikir kritis dalam pemecahan masalah matematika dan dapat membantu guru dalam membimbing selama proses pembelajaran berlangsung untuk mencapai hasil pembelajaran yang lebih baik. Sehingga hasil penelitian ini diharapkan dapat mendeskripsikan proses berpikir kritis siswa SMP dengan kepribadian choleris dalam pemecahan masalah matematika.

\section{METODE PENELITIAN}

Tujuan penelitian ini adalah untuk mendeskripsikan proses berpikir kritis siswa SMP dengan kepribadian choleris dalam pemecahan masalah matematika sehingga penelitian ini merupakan penelitian deskriptif kualitatif. Adapun penelitian ini dilaksanakan di MTs 
Hasanuddin Sidoarjo dengan pelaksanaan penelitian kurun waktu kurang lebih satu bulan dan sumber data dalam penelitian ini adalah siswa kelas VIII MTs Hasanuddin Sidoarjo. Penentuan kelas dipilih berdasarkan saran dari guru matematika yang didasarkan pada kesetaraan kemampuan matematika siswa dan komunikasi yang baik.

Pemilihan subjek penelitian berdasarkan hasil tes kepribadian yang diberikan oleh peneliti melalui google form yang terdiri dari 40 butir soal dengan kriteria jawaban A: Kepribadian Sanguinis, B: Kepribadian Choleris, C: Kepribadian Melankolis, D: Kepribadian Phlegmatis. yang kemudian diperoleh 12 kepribadian sanguinis, 12 siswa dengan kepribadian choleris, 6 siswa melankolis, dan 6 phlegmatis. Dari 12 siswa yang memiliki kepribadian choleris peneliti hanya memilih 2 subjek dengan meminta saran dari guru matematika terkait kemampuan matematikanya serta kemampuan komunikasinya. Setelah diperolah subjek yang diinginkan oleh peneliti, kemudian peneliti memberikan soal Tes Pemecahan Masalah Matematika (TPMM) serta melakukan wawancara semi terstruktur untuk memperoleh gambaran terkait kemampuan berpikir kritis siswa dalam pemecahan masalah matematika.

Teknik pengumpulan data pada penelitian ini adalah teknik tes yang terdiri dari Tes Kepribadian serta Tes Pemecahan Masalah (TPM) dan wawancara. Selanjutnya hasil yang telah diperoleh dari soal TPM dan wawancara kemudian direduksi, hasil TPM dipilah berdasarkan indikator pemecahan masalah sedangkan untuk hasil wawancara dipilah berdasarkan hal-hal yang dibutuhkan untuk mendapatkan informasi dan penguat dari hasil TPM siswa. Hasil TPM dan wawancara disajikan dalam bentuk teks yang bersifat naratif agar mudah dipahami. Penarikan kesimpulan didasarkan pada hasil analisis data yang telah dijelaskan pada tahap reduksi dan penyajian data. Selanjutnya penarikan kesimpulan ditujukan untuk mendeskripsikan proses berpikir kritis siswa SMP dengan kepribadian choleris dalam pemecahan masalah matematika. Apabila dalam pemberian tes dan wawancara antara kedua subjek diperoleh data yang sesuai maka data tersebut dianggap valid, namun apabila antara hasil tes dan wawancara tidak diperoleh data yang sesuai maka dilakukan pengambilan data kembali sampai mendapatkan data yang valid. Pada penelitian ini keabsahan data menggunakan triangulasi sumber untuk memperoleh data yang valid dan kredibel.

\section{HASIL DAN PEMBAHASAN Hasil Penelitian}

Hasil penelitian proses berpikir kritis siswa SMP dengan kepribadian choleris dalam pemecahan masalah matematika ini diperoleh dari paparan data tertulis dan wawancara. Berikut disajikan data hasil tes tulis dari TPM subjek dengan kepribadian choleris.

Berdasarkan hasil TPM pada Gambar 1 dan Gambar 2 dapat dilihat bahwa terdapat beberapa kesamaan dalam mengerjakan dan konsistensi jawaban subjek saat wawancara, sehingga dapat disimpulkan bahwa data tersebut kredibel atau valid. Berdasarkan 


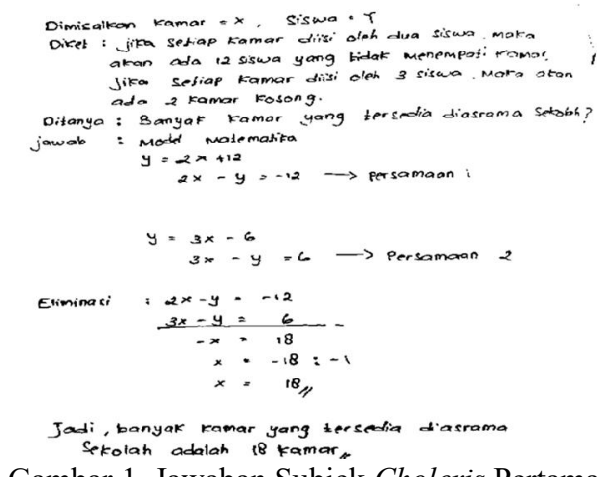

Gambar 1. Jawaban Subjek Choleris Pertama (SC1)

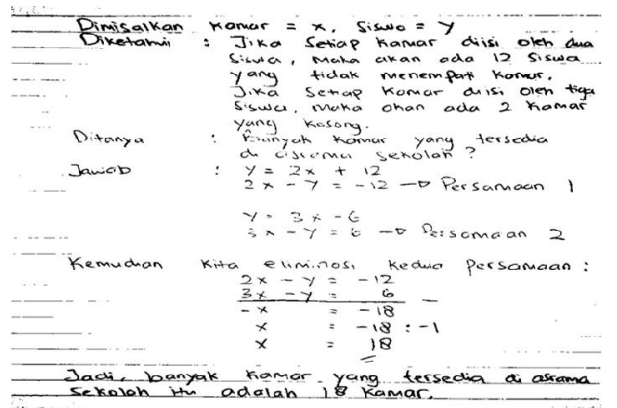

Gambar 2. Jawaban Subjek Choleris Kedua $(\mathrm{SC} 2)$

hasil analisis di atas diperoleh data berpikir kritis siswa SMP dengan kepribadian choleris dalam pemecahan masalah matematika pada tahap memahami masalah subjek choleris memenuhi keriteria berpikir kritis tahap focus, reason, inference, situation, clrity, overview yaitu menyatakan makna tentang masalah yang akan dipecahkan dengan cara merumuskan kembali masalah dengan membaca ulang soal serta menuliskan-nya pada lembar jawaban dan meng-gunakan variabel $x$ untuk menyatakan banyak kamar, variabel $y$ untuk menyatakan banyak siswa. Memberikan alasan terkait rumusan masalah yang telah dibuat agar saat pengoperasiannya lebih mudah dan jelas, karena variabelnya sudah ditentukan terlebih dahulu. Menjelaskan proses penarikan kesimpulan tentang masalah yang telah dibuat dengan bahasa mereka sendiri, yaitu setelah memahami soal dan menentukan variabel subjek dapat menyimpulkan bahwa permasalahan tersebut adalah materi sistem persamaan linear dua variabel berdasarkan penge-tahuan subjek tentang materi yang sudah diperoleh. Menyebutkan semua hal yang diketahui dan ditanyakan dalam soal dengan menuliskan kembali pada lembar jawaban. Menjelaskan istilah yang digunakan dalam berpendapat seperti membuat permisalan dengan variabel $x$ dan variabel $y$, selain itu juga subjek dapat menjelaskan pengertian dari variabel dan sistem persamaan linear dua variabel. Mengecek semua hal yang telah dilakukan dengan meneliti satu persatu apa yang telah ditulis pada lembar jawaban.

Pada tahap membuat rencana penyelesaian Subjek choleris memenuhi keriteria berpikir kritis focus, reason, inference, situation, clrity, overview yaitu menentukan strategi pemecahan masalah dengan melibatkan variabel yang telah ditentukan untuk membuat persamaan satu dan persamaan dua kemudian diselesaikan dengan menggunakan metode eliminasi. Memberikan alasan mengapa memilih menggunakan metode eliminasi sebagai strategi pemecahan masalah karena dianggap lebih mudah dari pada metode yang lain. menjelaskan proses penarikan kesimpulan menggunakan metode eliminasi dengan memberikan perbandingan pada metode dalam SPLDV yang lain, dan menghubungkan konsep yang sudah diperoleh dengan masalah yang diberikan saat ini. Mengetahui hal penting 
yang yang perlu diperhatikan seperti penentuan variabel, penentuan persamaan hingga metode yang sesuai untuk memecahkan masalah. Menjelaskan dengan detail dari mana memperoleh persamaan satu dan persamaan dua dengan menuliskan hasil persamaan pada lembar jawaban. Mengecek kembali strategi yang telah dipilih dengan membaca dan meneliti ulang persamaan yang ditulis karena akan berpengaruh untuk tahap selanjutnya.

Subjek choleris pada tahap melaksanakan rencana penyelesaian memenuhi kriteria berpikir kritis focus, reason, inference, situation, clrity, overview yaitu menjelaskan langkah penerapan strategi yang telah dipilih yaitu cara mengoperasikan metode eliminasi dan menuliskannya pada lembar jawaban. Memberikan alasan jika penerapan metode eliminasi adalah dengan mengeliminasi salah satu variabel dan subjek juga menghubungkan alasan yang dikemukakan dengan materi yang telah diperoleh. Menjelaskan proses penarikan kesimpulan berdasarkan hasil yang diperoleh dari langkah pengerjaan. Menjelaskan hal penting yang perlu diperhatikan dalam menerapkan metode eliminasi yaitu meneliti semua tahapan yang telah dilakukan serta meneliti perhitungannya. Menjelaskan istilah yang digunakan seperti kata "ruas kanan" pada saat mengerjakan soal. Memeriksa kembali langkah pengerjaan yang telah dilakukan dengan meneliti satu persatu tahapan pada langkah pemecahan masalah.

Sedangkan pada tahap memeriksa kembali, subjek choleris memenuhi kriteria berpikir kritis focus, reason,
Tabel 3. Hasil Analisis Berpikir Kritis Siswa SMP dengan Kepribadian Choleris dalam Pemecahan Masalah Matematika

\begin{tabular}{lll}
\hline $\begin{array}{c}\text { Tahap } \\
\text { Memecahan } \\
\text { Masalah }\end{array}$ & $\begin{array}{l}\text { Kriteria } \\
\text { Berpikir } \\
\text { Kritis }\end{array}$ & $\begin{array}{c}\text { Terpenuhi/ } \\
\text { Tidak Terpenuhi }\end{array}$ \\
\hline Memahami & Focus & Terpenuhi \\
Masalah & Reason & Terpenuhi \\
& Inference & Terpenuhi \\
& Situation & Terpenuhi \\
& Clarity & Terpenuhi \\
& Overview & Terpenuhi \\
Membuat & Focus & Terpenuhi \\
Rencana & Reason & Terpenuhi \\
Penyelesaian & Inference & Terpenuhi \\
& Situation & Terpenuhi \\
& Clarity & Terpenuhi \\
Melaksanakan & Overview & Terpenuhi \\
Focus & Terpenuhi \\
Penyelesaian & Reason & Terpenuhi \\
& Inference & Terpenuhi \\
& Situation & Terpenuhi \\
& Clarity & Terpenuhi \\
& Overview & Terpenuhi \\
Memeriksa & Focus & Terpenuhi \\
Kembali & Reason & Terpenuhi \\
& Inference & Terpenuhi \\
& Situation & Terpenuhi \\
& Clarity & Terpenuhi \\
& Overview & Tidak Terpenuhi \\
\hline & & \\
& & \\
& &
\end{tabular}

inference, situation, clarity, yakni memeriksa kembali jawaban dan merasa yakin dengan jawaban yang diperoleh karena hasil yang didapat sudah berupa angka dan tidak mengandung variabel. Memeriksa kembali dengan alasan untuk meneliti setiap tahap yang telah dilakukan dengan memperhatikan simbol atau variabel yang digunakan. Menjelaskan proses penarikan kesimpulan dengan memperhatikan langkah yang telah diterapkan untuk diteliti kebenarannya. Memeriksa hal penting yang perlu diperhatikan pada tahapan memahami masalah, membuat rencana dan melaksanakan rencana penyelesaian dan menjelaskan istilah yang digunakan dengan bahasa mereka sendiri. Tabel 3 adalah tabel berpikir 
kritis siswa SMP dengan kepribadian choleris dalam pemecahan masalah matematika berdasarkan hasil analisis di atas.

\section{Pembahasan}

Berdasarkan hasil penelitian menunjukkan bahwa subjek dengan kepribadian choleris dalam memecahkan masalah matematika pada tahap memahami masalah dapat memahami masalah dengan baik, dapat mengetahui apa yang diketahui dan ditanyakan dari soal juga menuliskannya pada lembar jawaban hal ini tidak sejalan dengan hasil penelitian yang dilakukan oleh (Sutrisno, A.B., et al. 2020) yang menyatakan bahwa subjek choleris tidak dapat memisahkan apa yang diketahui dan ditanya dari soal juga tidak menuliskannya pada lembar jawaban.

Pada tahap membuat rencana penyelesaian subjek choleris cenderung mengubah situasi soal ke dalam bentuk persamaan linear dua variabel dengan menyusun persamaan yang memuat variabel $x$ dan variabel $y$. Hal ini sejalan dengan hasil penelitian yang dilakukan oleh (Sutrisno, A.B., et al. 2020) bahawa subjek cenderung menggunakan symbol untuk memisalkan sesuatu dan menyusun dua buah persamaan yang memuat variabel tertentu.

Sedangkan pada tahap melaksanakan rencana penyelesaian subjek choleris langsung menggunakan strategi yang telah dipilih untuk memecahkan masalah tanpa menuliskan kembali soal. Subjek merasa bahwa langkah yang dipilih untuk memecahkan masalah sudah sesuai dengan masalah yang diberikan Hal ini sejalan dengan hasil penelitian yang dilakukan oleh (Purniance, R.F. 2018). Subjek memecahkan masalah dengan menggunakan metode eliminasi terhadap dua persamaan untuk memperoleh nilai dari variabel yang ditanyakan. Pada tahap ini subjek choleris berpikir kritis untuk menentukan persamaan dari situasi pada soal. Hal ini sesuai dengan yang dikemukakan oleh Ennis (dalam Siswono, 2018) bahwa berpikir kritis adalah suatu proses yang bertujuan untuk membuat keputusan-keputusan yang masuk akal tentang sesuatu yang dipercayai dan dilakukan. Dari proses berpikir kritis tersebut subjek choleris memperoleh persamaan satu $y=2 x+$ 12 dan persamaan dua $y=3 x-6$.

Setelah melaksanakan rencana, tahap selanjutnya memeriksa kembali jawaban yang diperoleh dengan melihat ulang apa yang diketahui dan ditanyakan pada soal, melihat langkah pengerjaan soal serta jawaban namun tidak menuliskannya pada lembar jawaban. Hal ini sejalan dengan hasil penelitian yang dilakukan oleh (Via, 2015; Simamora \& Saragih, 2019; Sutrisno, A.B. et al. 2020). Pada tahap ini Subjek tidak melalui indikator berpikir kritis overview, hal ini terjadi karena salah satu sifat choleris yang optimis pada sesuatu yang dikerjakan, sehingga tidak mengecek kembali angka yang diperoleh tersebut.

\section{SIMPULAN DAN SARAN}

Simpulan

Berdasarkan analisis dan pembahasan dapat disimpulkan bahwa siswa MTs Hasanuddin Sidoarjo kelas VIII dengan kepribadian choleris dalam 
pemecahan masalah matematika pada tahap memahami masalah subjek choleris memenuhi kriteria berpikir kritis focus, reason, inference, situation, clarity, overview. Pada tahap membuat rencana penyelesaian subjek choleris memenuhi keriteria berpikir kritis focus, reason, inference, situation, clarity, overview dan pada tahap melaksanakan rencana penyelesaian subjek choleris juga memenuhi keriteria berpikir kritis focus, reason, inference, situation, clarity, overview. Sedangkan pada tahap memeriksa kembali rencana penyelesaian subjek choleris memenuhi kriteria berpikir kritis focus, reason, inference, situation, clarity tetapi tidak memenuhi kriteria berpikir kritis overview.

\section{Saran}

Bagi peserta didik dengan adanya penelitian ini diharapkan agar peserta didik dapat mengembangkan kemampuan berpikir kritis dalam pemecahan masalah matematika untuk meningkatkan prestasi dan hasil belajar secara maksimal. Bagi guru dengan diketahuinya kepribadian siswa diharapkan agar dapat menentukan strategi dan model pembelajaran yang dapat meningkatkan kemampuan berpikir kritis siswa SMP dalam pemecahan masalah matematika sesuai dengan kepribadian yang dimiliki.

Bagi sekolah hendaknya memperhatikan kemampuan berpikir kritis siswa dalam pemecahan masalah matematika berdasarkan kepribadian yang dimiliki oleh setiap siswa dengan memfasilitasi media pembelajaran yang dapat meningkatkan kemampuan berpikir kritis dalam pemecahan masalah matematika. Bagi peneliti setelah adanya penelitian ini, diharapkan agar dapat dilanjutkan mengembangkan model pembelajaran matematika berdasarkan penggolongan tipe kepribadian dengan catatan hendaknya direfleksikan untuk diperbaiki.

\section{DAFTAR PUSTAKA}

Arini, Wahyu, Dan Fikri Juliadi. (2018). "Analisis Kemampuan Berfikir Kritis Pada Mata Pelajaran Fisika Untuk Pokok Bahasan Vektor Siswa Kelas X Sma Negeri 4 Lubuklinggau, Sumatera Selatan.” Journal Berlkala Fisika Indonesia 10(1): 1-11.

Chukwuyenum, A. N. (2013). Impact of critical thinking on performance in mathematics among senior secondary school students in Lagos State. IOSR Journal of Research \& Method in education, 3(5), 18-25.

Depdiknas. (2006). Peraturan Menteri Pendidikan Nasional Nomor 22 Tahun 2006 Tentang Standar Isi Untuk Satuan Pendidikan Dasae Dan Menengah. Jakarta: Depdiknas.

Dewanti, Sintha Sih. (2018). "Profil Berpikir Kritis Mahasiswa Pgmi Dalam Memecahkan Masalah Matematika Dasar." Jurnal Matematika Dan Pembelajaran 6(1): 11-22.

Harahap, Elvira Riska, Dan Edy Surya. (2017). "Kemampuan Pemecahan Masalah Matematis Siswa Kelas Vii Dalam Menyelesaikan Persamaan Linier Satu Variabel." Prosiding Seminar Nasional Matematika Universitas Negeri Medan: 553-58.

Hidayanti, Resky, Alimuddin, Andi Alim Syahri. (2020). "Analisis Kemampuan Berpikir Kritis 
Dalam Memecahkan Masalah Matematika Ditinjau Dari Perbedaan Gender Pada Siswa Kelas Vii.1 Smp Negeri 2 Labakkang." Sigma (Suara Intelektual Gaya Matematika) 12(1): 71-80.

Littauer, Florence. (1996). Personality Plus. Jakarta. Binapura Aksara.

Peter, E. E. (2012). Critical thinking: Essence for teaching mathematics and mathematics problem solving skills. African Journal of Mathematics and Computer Science Research, 5(3), 39-43.

Polya, G. (1973). How To Solve It (2nd Ed). Princeton, New Jersey: Princeton University Press.

Purniance, R.F., et al. (2018). "Analisis Proses Berpikir Kritis Siswa SMK Tipe Koleris dalam Memecahkan Masalah Matematika." Edu-Sains 7 no 1: 8-15.

Saudi, La, Muhammad Sudia, dan Mustamin Anggo. (2018). "Profil Berpikir Krtitis Siswa SMP Dalam Memecahkan Masalah Matematika Berdasarkan Gaya Kognitif." Jurnal Pendidikan Matematika 9(1): 92-101.

Siswono, Tatag yuli eko. (2018). Pembelajaran Matematika Berbasis Pengajuan dan Pemecahan Masalah. Pt. Remaja Rosdakarya. Bandung.

Simamora, R. E., \& Saragih, S. (2019). Improving Students' Mathematical Problem Solving Ability and SelfEfficacy through Guided Discovery Learning in Local Culture Context. International Electronic Journal of Mathematics Education, 14(1), 61-72.

Sutrisno, A.B., Et al. (2020). "Deskripsi Pemecahan Masalah Matematika berdasarkan Langkah Polya ditinjau dari Kepribadian Siswa Tipe koleris." ALFAmath(jurnal pendidikan matematika) 1 no 1.

Via, Y. (2015). Peningkatan Kemampuan Pemecahan Masalah Melalui Pengembangan Lembar Kegiatan Siswa (LKS) dengan Pendekatan Saintifik. Wahana: Tridharma Perguruan Tinggi, 64(1), 49-57.

Yustitia, V., \& Siswono, T. Y. E. (2021, June). Numeracy of prospective elementary school teachers: a case study. In Journal of Physics: Conference Series (Vol. 1918, No. 4, p. 042077). IOP Publishing. 